\title{
Brassica Green Manure Amendments for Management of Rhizoctonia solani in Two Annual Ornamental Crops in the Field
}

\author{
Kimberly A. Cochran and Craig S. Rothrock ${ }^{1}$ \\ Department of Plant Pathology, University of Arkansas, 217 Plant Science \\ Building, 495 North Campus Drive, Fayetteville, AR 72701
}

Additional index words. Rhizoctonia solani, Brassica napus, Brassica juncea, green manure, sustainable horticulture, petunia, impatiens

\begin{abstract}
Brassica green manure soil amendments are a possible alternative to chemical management of soilborne diseases of ornamental landscape and bedding plants. The objective of this study was to determine the importance of crop selection and application rate of brassica green manures for disease caused by Rhizoctonia solani on impatiens and petunia. Microplot experiments were conducted over 2 years using brassica green manure soil amendments for $R$. solani management of both petunias and impatiens. Brassica crops used were Brassica juncea 'Fumus' and 'Bionute', and Brassica napus 'Jetton', at the application rates of 700,1400 , and $4200 \mathrm{~g} \cdot \mathrm{m}^{-2}$ fresh weight aboveground biomass. Microplots were artificially infested to evaluate disease on these ornamentals, with a second set of experiments using noninfested plots to examine effects of the green manure alone on plant growth. All brassica green manure crops reduced disease symptoms in both impatiens and petunias. Rate of brassica application was more important than brassica crop variety for use as a green manure. The highest rate of the brassica green manure decreased crown lesions by $21 \%$ and $24 \%$, root discoloration by $9 \%$ and $7 \%$, and $R$. solani isolation by $15 \%$ and $8 \%$ for impatiens and petunias, respectively, for $4200 \mathrm{~g} \cdot \mathrm{m}^{-2}$ compared with $700 \mathrm{~g} \cdot \mathrm{m}^{-2}$ rates of application. No phytotoxic effects were observed from the brassica green manures following a waiting period of 4 weeks between amending the soil and planting the ornamental crops.
\end{abstract}

The use of brassica crop residues and seed meal to manage soilborne disease has gained interest as an alternative control strategy to traditional soil fumigants. Brassica soil amendments have been found to be effective in reducing soilborne pathogen populations of fungi, oomycetes and nematodes, and the diseases they cause (Mazzola and Strauss, 2013; Ochiai et al., 2007; Snapp et al., 2007; Zasada and Ferris, 2004). For example, Rhizoctonia populations in apple orchard soils and root rot of apple were reduced by $B$. napus seed meal (Cohen et al., 2005). B. juncea cover crop residues grown and incorporated into the soil were found to reduce root rot incidence caused by $R$. solani [teleomorph = Thanatephorus cucumeris (A.B. Frank) Donk] AG 2-2 IIIB on sugar beet (Motisi et al., 2009). Several different types of brassicas and rates of treatment have been used in previous studies (Mazzola et al., 2007; Ochiai et al., 2007; Rice et al., 2007; Yulianti et al., 2006; Yulianti et al., 2007; Zasada et al., 2003). For example, Mazzola et al. (2007) used seed meals of several brassicas with different

\footnotetext{
Received for publication 16 June 2014. Accepted for publication 5 Dec. 2014.

This research was funded in part by the Southern Sustainable Agriculture Research \& Education (SARE) Graduate Student Grant program.

${ }^{1}$ To whom reprint requests should be addressed; e-mail rothrock@uark.edu.
}

tively, disease suppression could be the result of changes in soil microbial communities or other mechanisms that result in the suppression of soilborne pathogens (Mazzola et al., 2007). Mazzola et al. (2007) determined that disease suppression of Rhizoctonia in apple was associated with streptomycete population changes in the soil. Studies by Cohen et al. (2005), Friberg et al. (2009) and Mattner et al. (2008) suggested that other mechanisms, including chemicals other than isothiocyanates or microbial population shifts leading to antagonism, may be responsible for suppression of soilborne pathogens.

Ornamental bedding plants are important crops for commercial production. $R$. solani AG4 causes crown and root rots on ornamentals including petunia (Wright et al., 2004) and impatiens (Diab et al., 2003; Honeycutt and Benson, 2001). The high cost of chemical treatments and label restrictions for soilborne diseases may limit disease management options for small-scale producers and homeowners. The use of brassica green manures is advantageous due to potential application in numerous production systems. Scale neutrality of brassica green manure production combined with the potential for environmental sustainability makes this disease management technique especially attractive for homeowners and small-scale producers. The objective of this study was to determine the importance of crop selection and application rate of brassica green manures on disease caused by $R$. solani on impatiens and petunia.

\section{Materials and Methods}

glucosinolate profiles to suppress Rhizoctonia spp. and $R$. solani AG5. Zasada et al. (2003) investigated the efficacy of broccoli soil amendments in managing Fusarium spp. using varying broccoli biomass (400-840 dry $\left.\mathrm{g} \cdot \mathrm{m}^{-2}\right)$ and concluded no disease or pathogen suppression was achieved with any rate of broccoli biomass. In contrast, Yulianti et al. (2007) found that higher rates of two different brassica green manure amendments suppressed $R$. solani more consistently than lower rates of application. Brassica soil amendment and green manure research on disease management on ornamental crops is limited. Studies include ornamental crops such as calla lily (Zasada et al., 2003) and peppermint (Berlanger, 1999), though pathogen suppression and disease control were inconsistent in these studies.

Efficacy of brassica soil amendments may vary based on rate, crop, environment, and method of delivery. Brassicas are thought to be effective in suppression of soilborne pathogens due to the release of isothiocyanates and other chemicals produced from the hydrolysis of glucosinolates (Fan et al., 2008). Glucosinolates are present at differing proportions in different species and cultivars of brassicas (Cohen et al., 2005; Gimsing and Kirkegaard, 2006; Zasada and Ferris, 2004). The release of these volatile compounds from plant amendments that have a negative impact on soilborne pathogens has been given the term biofumigation (Motisi et al., 2009). Alterna-
Experimental design. Microplot field experiments were conducted at the Arkansas Agricultural Research and Extension Center located in Fayetteville, AR in 2007 and 2008 to examine disease suppression of $R$. solani using varying brassica species or cultivars and application rates. Microplots were ceramic flue tiles (Acme Brick Co., Clarksville, AR) $(39 \mathrm{~cm} \times 39 \mathrm{~cm}$ wide $\times 55 \mathrm{~cm}$ deep $)$ buried in the ground. The soil was from the Arkansas River Valley in Crawford County, AR, with a textural analysis of sandy loam: $61.6 \%$ sand, $30.5 \%$ silt, and $7.9 \%$ clay. The microplots had not been cultivated for several years, and had not been used to conduct experiments using this soilborne pathogen previously. Before treatments were applied, soil samples were taken from several plots and bulked for both controls and treated plots separately to perform soil fertility, textural analysis, and checked for $R$. solani populations. Soil fertility analysis was performed on a subsample of each of the bulked samples before planting the crops by the University of Arkansas Agricultural Experiment Station Soil Testing and Research Laboratory. Before the start of the second season of experiments, soil was removed from all plots to a depth of $\approx 30 \mathrm{~cm}$ and steam pasteurized at $70{ }^{\circ} \mathrm{C}$ for $30 \mathrm{~min}$.

Each experiment had 10 treatments: a nonamended control and three rates of each of the three brassica crops. Separate experiments 
were conducted for each ornamental. Each experiment was a randomized complete block design with five replications, and a different randomization for each of the 2 years of the study. In addition to the infested experiments, separate experiments with two repetitions (blocks) of all treatments and no pathogen infestation were performed for both ornamentals in the same experimental area at the same time.

Inoculum preparation and infestation. Inoculum was prepared in new $3.8 \mathrm{~L}$ plastic milk jugs filled with $950 \mathrm{~mL}$ of deionized water and $827 \mathrm{~g}$ of proso millet seed (Panicum miliaceum L.) and sealed with foam plugs. The jugs were autoclaved at $121^{\circ} \mathrm{C}$ twice, for 30 min each time, $24 \mathrm{~h}$ apart. Stock cultures of a virulent isolate of $R$. solani AG-4 originally from cotton in Clarkedale, AR, were grown on potato dextrose agar (PDA) (Difco, Becton, Dickinson and Company, Sparks, MD) for 7$10 \mathrm{~d}$. Several $2 \mathrm{~mm} \times 2 \mathrm{~mm}$ square pieces of a culture were aseptically placed in each jug. Jugs were incubated for 10 to $14 \mathrm{~d}$ before use and shaken once every other day to allow uniform colonization. Inoculum was applied to the soil at a rate of 25 colonized seed per $1000 \mathrm{~g}$ (oven dry weight) of soil, and sufficient inoculum was added to each microplot to infest the top $15 \mathrm{~cm}$ of soil.

Brassica treatments. Brassica green manure treatments consisted of biomass of Indian mustard (B. juncea) 'Fumus' and 'Bionute', and canola (B. napus) 'Jetton'. Rates of 700, 1400 , and $4200 \mathrm{~g} \cdot \mathrm{m}^{-2}$ aboveground fresh tissue were used. The rate of aboveground brassica biomass per square meter was based on field biomass production of $1400 \mathrm{~g} \cdot \mathrm{m}^{-2}$ when 'Fumus' seed was broadcast in field studies in Arkansas (Bates and Rothrock, 2006). Thus, rates were $0.5,1.0$, and 3.0 times the normal field biomass. 'Fumus' is a cultivar bred for high glucosinolate levels (Kirkegaard and Sarwar, 1999; Morra and Kirkegaard, 2002).

Field-grown brassica tissue was collected and washed free of any remaining field soil. In 2007, the 'Bionute' crop was collected from a field near Helena, AR, the 'Fumus' crop was collected from field plots near Portland, AR, and 'Jetton' canola was collected from plots near Kibler, AR at the University of Arkansas Vegetable Research Station. In 2008, all three crops were grown and collected from the Vegetable Research Station. Entire plants were collected, including as much of the root system as possible. Plants were then transported back to Fayetteville and kept in refrigeration at $4{ }^{\circ} \mathrm{C}$ for no longer than $3 \mathrm{~d}$ before incorporation. Relative amounts of root mass compared with aboveground tissue were calculated for each brassica crop so that green manure amendments could be based on field results for aboveground biomass. Biomass was chopped into small sections 3-6-cm long using hand clippers, just before incorporation. Roots were included in the biomass applied. After chopping, the biomass was incorporated to a depth of $15 \mathrm{~cm}$ in each microplot using trowels and garden spades. $R$. solani infested plots had brassica tissue incorporated after the non- infested plots, and hand tools were sanitized between plots as appropriate. After incorporation of inoculum and biomass, plots were manually overhead irrigated equivalent to $2.5 \mathrm{~cm}$ of rainfall and soil moisture monitored from this point until termination of the experiment. Incorporation and infestation occurred on 20 Mar. 2007 and 18 Apr. 2008. Weekly average high and low air temperatures the first week after incorporation were 23.9 to $13.8^{\circ} \mathrm{C}$ and 24.0 to $10^{\circ} \mathrm{C}$ for 2007 and 2008 , respectively.

Crop production. Petunia (Petunia axillaries $\times P$. integrifolia Schinz \& Thell) 'Bobby Dazzler' and impatiens (Impatiens wallerana L.) 'Dazzler Mix' were selected for use in this study due to their popularity as bedding plants. Transplants were selected for uniform size and obtained from Parks Brothers Farm, Inc., Van Buren, AR.

About 4 weeks postincorporation of the green manures, 10 young plants of petunia or impatiens were transplanted into each microplot. For the noninfested experiments, microplots were planted so that each plot had five impatiens and five petunias. Noninfested plots were transplanted before all infested plots to prevent contamination. Planting of the ornamental crops occurred on 20 Apr. 2007 and 15 May 2008. A Watchdog (Spectrum Technologies, Inc., Plainfield, IL) temperature and Watermark moisture sensor were placed in a random microplot of each replication $10 \mathrm{~cm}$ deep to monitor soil environment. After planting, all microplots were thoroughly irrigated. After initial irrigation, plots were watered when the matric potential reached between -20 and $-30 \mathrm{~J} \cdot \mathrm{kg}^{-1}$ as indicated by soil moisture sensors until termination of the experiment. Plants were periodically fertilized with water-soluble fertilizer $(24 \mathrm{~N}-8 \mathrm{P}$ 16K) (Miracle Gro Water Soluble All Purpose Plant Food, The Scotts Company, LLC, Marysville, $\mathrm{OH}$ ) as per label instructions.

Data collection. After 4 weeks, plants were dug from plots for analysis. Soil around the crown and root sections was washed off and removed from the aboveground tissue. Roots were clipped from the aboveground biomass. After removal of soil and washing, the roots were weighed and the aboveground tissue oven dried at $60{ }^{\circ} \mathrm{C}$ and weighed.

Root discoloration was rated on a scale of $0=0 \%, 1=1 \%$ to $20 \%, 2=21 \%$ to $40 \%, 3=$ $41 \%$ to $60 \%, 4=61 \%$ to $80 \%$, and $5=81 \%$ to $100 \%$ discoloration. Crown disease was rated in 2008 on a qualitative scale as follows: $1=$ healthy, 2 = discoloration, 3 = lesion, $4=$ large or several lesions, and $5=$ girdling lesions. After rating each plant for disease symptoms, the belowground tissue was rinsed for $20 \mathrm{~min}$ with water, disinfested in $0.5 \% \mathrm{NaClO}$ for $1.5 \mathrm{~min}$, and plated on $\mathrm{Ko}$ and Hora selective medium (Ko and Hora, 1971) to isolate the pathogen, if present. After $24-48 \mathrm{~h}$, plates were examined for suspected colonies of $R$. solani, which were transferred to PDA amended with rifampicin (10 $\mathrm{mg} \cdot \mathrm{L}^{-1}$ dissolved in dimethylsulfoxide), ampicillin $\left(0.25 \mathrm{~g} \cdot \mathrm{L}^{-1}\right)$, and the miticide fenpropathrin $\left(0.14 \mathrm{mg} \cdot \mathrm{L}^{-1}\right.$ a.i., Danitol 2.4
EC, Valent USA Corp, Walnut Creek, CA). Cultures were identified by cultural and morphological characteristics of $R$. solani and multinucleate state confirmed by nuclear staining (Tu and Kimbrough, 1973).

Statistical analyses. Each ornamental crop was analyzed separately. Root discoloration was analyzed as midpercentile values. Crown rating was analyzed as the percentage of plants with a crown lesion rating of 3 or greater. Data were analyzed across years using generalized linear model. Means were separated with Fisher's protected least significant difference (LSD) using SAS (SAS Institute Inc., Cary, NC). To determine if there was a green manure fertility effect, the experiments were analyzed by green manure treatment across the rate treatments, and were compared with the no brassica treatment. To examine the effects of brassica crop and rate of application, the nonamended treatment was deleted and the analysis was conducted as a factorial treatment arrangement of brassica crop and rate of amendment. The noninfested experiments were analyzed as separate experiments.

\section{Results}

Data for the petunia or impatiens experiments were combined across years as a result of no significant year by treatment interaction: impatiens $(P=0.1473)$ and petunias $(P=0.8963)$. There was also no interaction between brassica green manure crop and rate of application allowing rate of application to be examined across brassica crop: impatiens $(P=0.5183)$ and petunias $(P=0.1138)$. In both the petunia and impatiens experiments across years, rate of brassica green manure had the greatest impact on disease symptoms and percent isolation of $R$. solani. The highest rate of brassica green manure had a reduction of disease symptoms compared with the two lower rates for crown lesions and root discoloration for impatiens (Table 1) and petunias (Table 2). Isolation of $R$. solani was lowest for the highest rate of brassica green manure compared with the lowest rate, but not different from the intermediate rate. Comparing the $4200 \mathrm{~g} \cdot \mathrm{m}^{-2}$ rate to the 700 $\mathrm{g} \cdot \mathrm{m}^{-2}$ rate, crown lesions of impatiens were observed to be reduced by $21.4 \%$, root discoloration by $8.6 \%$, and $R$. solani isolation by $15.2 \%$. The $4200 \mathrm{~g} \cdot \mathrm{m}^{-2}$ rate of application reduced crown lesions on petunias by $24.3 \%$, root discoloration by $6.6 \%$, and isolation of $R$. solani by $8.1 \%$ when compared with the $700 \mathrm{~g} \cdot \mathrm{m}^{-2}$ rate of application.

All brassica crop green manure treatments were significantly different from the no brassica control, but similar to each other for percent crown lesions or root discoloration (Tables 1 and 2). In addition, frequency of isolation of $R$. solani from plants was reduced with brassica green manure application, with no differences among brassica crops.

Plant growth of petunias and impatiens were unaffected by the brassica crop treatments compared with the nonamended treatment or the rate of application for either 
Table 1. Effects of brassica green manure crop and rate of application on plant growth, disease symptoms, and Rhizoctonia solani isolation frequency from impatiens. ${ }^{2}$

\begin{tabular}{|c|c|c|c|c|c|c|}
\hline Main effect & Treatment & $\begin{array}{l}\text { Plant top } \\
\text { dry wt }(\mathrm{g})\end{array}$ & $\begin{array}{l}\text { Plant root } \\
\text { fresh wt }(\mathrm{g})\end{array}$ & $\begin{array}{l}\text { Plants with } \\
\text { crown } \\
\text { lesions }(\%)^{\mathrm{y}}\end{array}$ & $\begin{array}{c}\text { Root } \\
\text { discoloration } \\
(\%)^{\mathrm{x}}\end{array}$ & $\begin{array}{l}\text { Isolation of } \\
R . \text { solani }(\%)\end{array}$ \\
\hline \multirow[t]{5}{*}{$\mathrm{Crop}^{\mathrm{w}}$} & Bionute & $3.03 \mathrm{a}^{\mathrm{v}}$ & $9.20 \mathrm{a}$ & $35.9 \mathrm{~b}$ & $22.3 \mathrm{~b}$ & $62.4 \mathrm{~b}$ \\
\hline & Fumus & $3.36 \mathrm{a}$ & $9.61 \mathrm{a}$ & $38.0 \mathrm{~b}$ & $23.8 \mathrm{~b}$ & $68.0 \mathrm{~b}$ \\
\hline & Jetton & $3.46 \mathrm{a}$ & $10.36 \mathrm{a}$ & $35.6 \mathrm{~b}$ & $24.8 \mathrm{~b}$ & $58.3 \mathrm{~b}$ \\
\hline & None & $3.08 \mathrm{a}$ & $8.21 \mathrm{a}$ & $74.0 \mathrm{a}$ & $34.4 \mathrm{a}$ & $82.1 \mathrm{a}$ \\
\hline & $P$ value & 0.8144 & 0.1265 & 0.0035 & 0.0004 & 0.0075 \\
\hline \multirow[t]{4}{*}{ Rate $^{\mathrm{u}}$} & $700 \mathrm{~g} \cdot \mathrm{m}^{-2}$ & $3.08 \mathrm{a}$ & $9.28 \mathrm{a}$ & $44.1 \mathrm{a}$ & $27.4 \mathrm{a}$ & $71.2 \mathrm{a}$ \\
\hline & $1400 \mathrm{~g} \cdot \mathrm{m}^{-2}$ & $3.09 \mathrm{a}$ & $9.30 \mathrm{a}$ & $42.7 \mathrm{a}$ & $24.9 \mathrm{a}$ & $65.0 \mathrm{ab}$ \\
\hline & $4200 \mathrm{~g} \cdot \mathrm{m}^{-2}$ & $3.69 \mathrm{a}$ & $10.66 \mathrm{a}$ & $22.7 \mathrm{~b}$ & $18.8 \mathrm{~b}$ & $56.0 \mathrm{~b}$ \\
\hline & $P$ value & 0.2026 & 0.1056 & 0.0071 & $<0.0001$ & 0.0224 \\
\hline
\end{tabular}

${ }^{\mathrm{z}}$ Data were combined across 2007 and 2008 unless otherwise noted.

${ }^{y}$ Crown symptoms were assessed as 1 = healthy, 2 = discoloration, $3=$ lesion, $4=$ large or several lesions, and $5=$ girdling lesions. Analysis was conducted using percentage of plants assigned a rating of 3 or greater. Data were only collected in 2008.

${ }^{x}$ Root discoloration was assessed as $0=0 \%, 1=1 \%$ to $20 \%, 2=21 \%$ to $40 \%, 3=41 \%$ to $60 \%, 4=61 \%$ to $80 \%$, and $5=81 \%$ to $100 \%$ discoloration. Analysis was conducted using midpercentile values of assigned ratings.

${ }^{\text {w}}$ Analysis was conducted across all brassica rates for each crop.

${ }^{v}$ Means in a column for crop or rate followed by a common letter are not significantly different, protected LSD at $P \leq 0.05$

"Rate of brassica application and brassica crop were run as a factorial experiment without the nonamended treatment. The rate by crop interaction was not significant $(P=0.5183)$; therefore, the rates are presented across brassica crop.

Table 2. Effects of brassica green manure crop and rate of application on plant growth, disease symptoms, and Rhizoctonia solani isolation frequency from petunias. ${ }^{2}$

\begin{tabular}{|c|c|c|c|c|c|c|}
\hline Main effect & Treatment & $\begin{array}{l}\text { Plant top } \\
\text { dry wt }(\mathrm{g})\end{array}$ & $\begin{array}{l}\text { Plant root } \\
\text { fresh wt }(\mathrm{g})\end{array}$ & $\begin{array}{c}\text { Plants with } \\
\text { crown lesions } \\
(\%)^{\mathrm{y}}\end{array}$ & $\begin{array}{c}\text { Root } \\
\text { discoloration } \\
(\%)^{\mathrm{x}}\end{array}$ & $\begin{array}{c}\text { Isolation of } \\
R . \text { solani }(\%)\end{array}$ \\
\hline \multirow[t]{5}{*}{$\mathrm{Crop}^{\mathrm{w}}$} & Bionute & $2.75 \mathrm{a}^{\mathrm{v}}$ & $4.08 \mathrm{a}$ & $30.6 \mathrm{~b}$ & $18.0 \mathrm{~b}$ & $60.4 \mathrm{~b}$ \\
\hline & Fumus & $2.38 \mathrm{a}$ & $3.99 \mathrm{a}$ & $38.1 \mathrm{~b}$ & $18.7 \mathrm{~b}$ & $62.1 \mathrm{~b}$ \\
\hline & Jetton & $2.54 \mathrm{a}$ & $4.02 \mathrm{a}$ & $38.9 \mathrm{~b}$ & $19.2 \mathrm{~b}$ & $65.9 \mathrm{~b}$ \\
\hline & None & $2.12 \mathrm{a}$ & $3.85 \mathrm{a}$ & $88.0 \mathrm{a}$ & $28.7 \mathrm{a}$ & $77.1 \mathrm{a}$ \\
\hline & $P$ value & 0.1015 & 0.4984 & $<0.0001$ & 0.0002 & 0.0049 \\
\hline \multirow[t]{4}{*}{ Rate $^{u}$} & $700 \mathrm{~g} \cdot \mathrm{m}^{-2}$ & $2.41 \mathrm{a}$ & $4.13 \mathrm{a}$ & $43.4 \mathrm{a}$ & $21.2 \mathrm{a}$ & $66.6 \mathrm{a}$ \\
\hline & $1400 \mathrm{~g} \cdot \mathrm{m}^{-2}$ & $2.63 \mathrm{a}$ & $3.94 \mathrm{a}$ & $44.6 \mathrm{a}$ & $19.9 \mathrm{a}$ & $63.4 \mathrm{ab}$ \\
\hline & $4200 \mathrm{~g} \cdot \mathrm{m}^{-2}$ & $2.63 \mathrm{a}$ & $4.03 \mathrm{a}$ & $19.1 \mathrm{~b}$ & $14.6 \mathrm{~b}$ & $58.5 \mathrm{~b}$ \\
\hline & $P$ value & 0.3986 & 0.6398 & 0.0002 & $<0.0001$ & 0.0282 \\
\hline
\end{tabular}

${ }^{\mathrm{z}}$ Data were combined across 2007 and 2008 unless otherwise noted.

${ }^{y}$ Crown symptoms were assessed as 1 = healthy, 2 = discoloration, $3=$ lesion, $4=$ large or several lesions, and $5=$ girdling lesions. Analysis was conducted using percentage of plants assigned a rating of 3 or greater. Data were only collected in 2008 .

${ }^{x}$ Root discoloration was assessed as $0=0 \%, 1=1 \%$ to $20 \%, 2=21 \%$ to $40 \%, 3=41 \%$ to $60 \%, 4=61 \%$ to $80 \%, 5=81 \%$ to $100 \%$ discoloration. Analysis was conducted using midpercentile values of assigned ratings.

${ }^{w}$ Analysis was conducted across all brassica rates for each crop.

${ }^{\mathrm{N}}$ Means in a column for crop or rate followed by a common letter are not significantly different, protected LSD at $P \leq 0.05$.

"Rate of brassica application and brassica crop were run as a factorial experiment without the nonamended treatment. The rate by crop interaction was not significant $(P=0.1138)$; therefore, the rates are presented across brassica crop.

ornamental crop (Tables 1 and 2). Furthermore, for the noninfested experiments, brassica green manure treatments did not show any negative phytotoxic or positive fertility effects for a brassica crop or for rate of application compared with the nonamended control for top or root weight (data not shown).

\section{Discussion}

Brassica cultivar or crop did not differ when used as a green manure for management of crown and root rot caused by $R$. solani. However, rate of brassica green
Kirkegaard, 2006). However, despite the differences in end breakdown products, and the fact that $B$. napus has been found to have a glucosinolate to isothiocyanate conversion efficiency of about half of $B$. juncea, disease symptom suppression and pathogen recovery in this study was similar among the brassica crops. These results suggest that specific chemistry of breakdown products is less important in disease suppression than amount of brassica tissue.

Other research has used multiple amendment rates and brassica crops. Yulianti et al (2007) found two brassica species, Diplotaxis tenuifolia and Brassica nigra, which suppressed $R$. solani and the rate of application of $1 \%$ fresh amendment ( $1 \mathrm{~g}$ per $100 \mathrm{~g}$ soil $)$ was not as consistently effective as $5 \%(5 \mathrm{~g}$ per $100 \mathrm{~g}$ soil) fresh material. The highest rate of application in this study was most effective in reducing disease symptoms and was less than $3 \%$ fresh weight. Ochiai et al. (2007) examined the efficacy of various green manure crops and their rate of application on suppressing verticillium wilt of potato, incited by Verticillium dahliae. Green manures used included broccoli (Brassica oleracea) 'Excelsior', winter pea (Pisum sativum) 'Melrose', and sudan grass (Sorghum vulgare) 'Monarch', and rates used were 600 , 1200 , and $2400 \mathrm{~g} \cdot \mathrm{m}^{-2}$ dry biomass. Ochiai et al. (2007) found that broccoli treatments reduced inoculum of the pathogen at all rates of application, while pea and sudan grass reduced inoculum only at the high level of application. Unlike the current study, root infection rates were not reduced by any green manure treatment. However, wilt symptom severity was reduced by $\approx 70 \%$ by all green manures at their highest levels of application, and smaller reductions were observed with lower rates of application. Brassica green manure application rates were lower in this study than Ochiai et al. (2007), with the highest rate at $4200 \mathrm{~g} \cdot \mathrm{m}^{-2}$ fresh weight, which is less brassica material due to moisture content. The current study reinforces the findings of Yulianti et al. (2007) and Ochiai et al. (2007) that rate of application has a significant impact on disease management.

None of the brassica crops in this study appeared to have phytotoxic effects on petunias or impatiens when applied about 4 weeks before transplanting, even at the highest levels of application, which is similar to the findings of other research. For example, Dhingra et al. (2004) found no phytotoxicity in common bean (Phaseolus vulgaris) from amendments of B. napus 'Athena' and 'Sunrise', B. juncea 'Pacific Gold', or Sinapis alba 'Ida Gold' $10 \mathrm{~d}$ before planting. Dhingra et al. (2004) applied brassica crops to field plots at rates of $1 \mathrm{~g}$ per $100 \mathrm{~g}$ soil $(1 \%)$ and $3 \mathrm{~g}$ per $100 \mathrm{~g}$ soil $(3 \%)$ while the highest brassica rate in this study was $4200 \mathrm{~g} \cdot \mathrm{m}^{-2}(<3 \%)$. Rice et al. (2007) reported field crop emergence of lettuce and beet were usually not reduced by brassica seed meal amendments when crops were planted $28 \mathrm{~d}$ post incorporation of the seed meal. In research by Bates (2006), a period of $\approx 30 \mathrm{~d}$ was needed to minimize 
phytotoxicity of B. napus for several field crops. Other research suggests that what was previously thought to be a phytotoxic effect of amendments was in fact due to increased pathogen activity as a result of the recent organic amendment (Yulianti et al., 2006).

In this study and cited research, the brassica green manure treatments were added to the soil instead of growing brassicas on-site; therefore, the effect of on-site root growth is likely underestimated. Results from the application of brassica green manure may be more consistent and more effective if grown on-site due to reported benefits from microflora changes (Cohen et al., 2005) and extended long-term, multiyear effects of brassica treatments (Mazzola and Strauss, 2013). In landscape plantings, organic amendments such as green manures are frequently used to improve soil characteristics and quality. Using brassica green manures as an additional organic amendment to manage disease offers one way to foster disease suppression in landscape ornamental plantings.

The results from these experiments with impatiens and petunias indicate that rate of application of brassica green manures has a larger role in disease control than brassica green manure crop selection. The use of brassica green manures appear to be a viable option for controlling $R$. solani in landscapes as demonstrated with petunias and impatiens.

\section{Literature Cited}

Bates, G.D. 2006. Phytochemicals and their effects on soilborne organisms. University of Arkansas, Fayetteville, AR. PhD Diss. UMI 32-73753.

Bates, G.D. and C.S. Rothrock. 2006. Use of high glucosinolate Indian mustard cover crops to suppress soilborne pathogens of cotton. Phytopathology 96:S10.

Bending, G.D. and S.D. Lincoln. 1999. Characterization of volatile sulphur-containing compounds produced during decomposition of Brassica juncea tissues in soil. Soil Biol. Biochem. 31:695703.

Berlanger, I.E. 1999. Effect of a broccoli green manure, soil solarization, and isolates of Verticillium dahliae on verticillium wilt of agro- nomic and nursery crops. Oregon State University, Corvallis, OR. MS Thesis.

Cohen, M.F., H. Yamasaki, and M. Mazzola. 2005. Brassica napus seed meal soil amendment modifies microbial community structure, nitric oxide production and incidence of Rhizoctonia root rot. Soil Biol. Biochem. 37:1215-1227.

Dhingra, O.D., M.L.N. Costa, G.J. Silva, Jr., and E. S.G. Mizubuti. 2004. Essential oil of mustard to control Rhizoctonia solani causing seedling damping-off and seedling blight in nursery. Fitopatol. Bras. 29:683-686.

Diab, H.G., S. Hu, and D.M. Benson. 2003. Suppression of Rhizoctonia solani on impatiens by enhanced microbial activity in composted swine waste-amended potting mixes. Phytopathology 93:1115-1123.

Fan, C.M., G.R. Xiong, P. Qi, G.H. Ji, and Y.Q. He. 2008. Potential biofumigation effects of Brassica oleracea var. caulorapa on growth of fungi. J. Phytopathol. 156:321-325.

Friberg, H., V. Edel-Hermann, C. Faivre, N. Gautheron, L. Fayolle, V. Faloya, F. Montfort, and C. Steinberg. 2009. Cause and duration of mustard incorporations effects on soil-borne plant pathogenic fungi. Soil Biol. Biochem. 41:2075-2084.

Gimsing, A.L. and J.A. Kirkegaard. 2006. Glucosinolate and isothiocyanate concentration in soil following incorporation of Brassica biofumigants. Soil Biol. Biochem. 38:2255-2264.

Honeycutt, E.W. and D.M. Benson. 2001. Formulation of binucleate Rhizoctonia spp. and biocontrol of Rhizoctonia solani on impatiens. Plant Dis. 85:1241-1248.

Kirkegaard, J.A. and M. Sarwar. 1999. Glucosinolate profiles of Australian canola (Brassica napus annua L.) and Indian mustard (Brassica juncea L.) cultivars: Implications for biofumigation. Austral. J. Agr. Res. 50:315-324.

Ko, W. and F.K. Hora. 1971. A selective medium for the quantitative determination of Rhizoctonia solani in soil. Phytopathology 61:707-710.

Mattner, S.W., I.J. Porter, R.K. Gounder, A.L. Shanks, D.J. Wren, and D. Allen. 2008. Factors that impact on the ability of biofumigants to suppress fungal pathogens and weeds of strawberry. Crop Prot. 27:1165-1173.

Mazzola, M., J. Brown, A.D. Izzo, and M.F. Cohen. 2007. Mechanism of action and efficacy of seed meal-induced pathogen suppression differ in a Brassicaceae species and timedependent manner. Phytopathology 97:454460 .
Mazzola, M. and S.L. Strauss. 2013. Resilience of orchard replant soils to pathogen re-infestation in response to Brassicaceae seed meal amendment. Asp. Appl. Biol. 119:69-77.

Morra, M.J. and J.A. Kirkegaard. 2002. Isothiocyanate release from soil-incorporated Brassica tissues. Soil Biol. Biochem. 34:1683-1690.

Motisi, N., F. Montfort, V. Faloya, P. Lucas, and T. Dore. 2009. Growing Brassica juncea as a cover crop, then incorporating its residues provide complementary control of Rhizoctonia root rot of sugar beet. Field Crops Res. 113:238-245.

Ochiai, N., M.L. Powelson, R.P. Dick, and F.J. Crowe. 2007. Effects of green manure type and amendment rate on Verticillium Wilt severity of Russet Burbank potato. Plant Dis. 91:400-406.

Rice, A.R., J.L. Johnson-Maynard, D.C. Thill, and M.J. Morra. 2007. Vegetable crop emergence and weed control following amendment with different Brassicaceae seed meals. Renew. Agr. Food Syst. 22:204-212.

Snapp, S.S., K.U. Date, W. Kirk, K. O’Neil, A. Kremen, and G. Bird. 2007. Root, shoot tissues of Brassica juncea and Cereal secale promote potato health. Plant Soil 294:55-72.

Tu, C.C. and J.W. Kimbrough. 1973. A rapid staining technique for Rhizoctonia solani and related fungi. Mycologia 65:941-944.

Wright, E.R., M.C. Rivera, and K. Asciutto. 2004. First report of petunia root rot caused by Rhizoctonia solani in Argentina. Plant Dis. 88:86.

Yulianti, T., K. Sivasithamparam, and D.W Turner. 2007. Saprophytic and pathogenic behavior of R. solani AG2-1 (ZG-5) in a soil amended with Diplotaxis tenuifolia or Brassica nigra manures and incubated at different temperature and soil water content. Plant Soil 294:277-289.

Yulianti, T., K. Sivasithamparam, and D.W. Turner. 2006. Saprophytic growth of Rhizoctonia solani Kühn AG2-1 (ZG5) in soil amended with fresh green manures affects the severity of damping-off in canola. Soil Biol. Biochem. 38:923-930.

Zasada, I.A., H. Ferris, C.L. Elmore, J.A. Roncoroni, J.D. MacDonald, L.R. Bolkan, and L.E. Yakabe. 2003. Field application of brassicaceous amendments for control of soilborne pests and pathogens. Online. Plant Health Prog., doi:10.1094/ PHP-2003-1120-01-RS.

Zasada, I.A. and H. Ferris. 2004. Nematode suppression with bassicaceous amendments: Application based upon glucosinolates profiles. Soil Biol. Biochem. 36:1017-1024. 